Groom bridge: Catalogue. - In First Radcliffe catalogue.

- Bonn obs., vi

Heis: Atlas coelestis. - Annals Harv. coll. obs., ix. - v. J. s. viii. 67,278 ; ix. 236 ; xiii. 111.

Herschel: Gen. cat. nebulae and clusters. - v. J. s. $1866,176$.

1876,61

Johnson: First Radcliffe catalogue. - Bonn obs., vi.

Lacaille: Coelum australe stelliferum. - Bonn obs., vii.

Lalande: Catalogue. - Monthly not. R. A. S., xiv.

195. [This volume I have not access to at present.]

- Histoire céleste. - Bonn obs., vii.

Observations of 1789-90. - Bonn obs., vi.

- Catalogue. - Cooper's Ecliptic stars, iv.

Lamont: Catalogues (6 vols.) - v. J. s. ix. 94 .

Main, R. : 2d Radcliffe catalogue. - v. J. s. 1870 292.

Newcomb, S.: On the R. Asc. of the eq. fund. stars. - v. J. s. $1876,158$.

Catalogue of 1,098 stars. - v. J. s. 1882,259 .

Piazzi: Positiones mediae, 1814. - Bonn obs., vi.

Rümker: 12,000 stars. - Bonn obs., vi.

- Cooper's Ecliptic stars, iv.

Neuer folge. - Bonn obs., vi.

Preliminary catalogue of southern stars. -

Stone, Cape catalogue, 1880.

Santini: First two catalogues. - Bonn obs., vi.

- Posizioni medie di 1,425 stelle. - v. J. s.

1872,13 .

Schjellerup: Al-Sufi's Uranometry. - Monthly not.

R. A. S., xliii. 266 .

10,000 stars. - Bonn obs., vi.

Sclı̈nfeld, E. : Catalog von veränderlichen sternen. - v. J. s. 1866,113

Z Zweiter catalog von veränderlichen sternen. v. J. s. 1875,73 .

Stone, E. J.: Results of astronomical observations at Cape of Good Hope, 1856-58. - v. J. s. 1875, 192

- Cape catalogue, 1880. - v. J. s. 1880, 297.

Strasser: Mittlere oerter von fixsternen. - v. J. s. $1878,88$.

Struve (W.): Positiones mediae. - Bonn obs., vi. - Schjellerup's 10,000 stars, p. 225 .

Taylor: Madras catalogue. - Bonn obs., vi.; Cape catalogue, 1840; same, 1880.

- Astron. obs. at Madras, 1843-47.- v. J. s. 1873,180 .

Vogel, H. C.: Positionsbestimmungen von nebelflecken, etc. - v. J. s. $1876,276$.

Weisse's Bessel's Zones, +15 0 to $-15^{\circ}$. - Cooper's Ecliptic stars, iv.

- Gould's Astronomical journal, iii. 115. [This contains all the errata of the Astr. nachr. up to 1853, June.]

- Annals Harv. coll. observatory, i., pt. ii., p. Iviii.

- Schjellerup's 10,000 stars, p. 225.

xlv.

- Weisse's Bessel's Zones, $+15^{\circ}$ to $+45^{\circ}, \mathrm{p}$.

"Catalogue." - Monthly not. R. A. S., xiv.

195. [This volume $I$ have not access to at present.]

Wilson \& Seabroke: Catalogue of measures of double stars. - v. J. s. 1877, 108.

Yarnall: Catalogue U. S. naval obs. - v. J. s. $1880,20$.

The search for Crevaux.

Apropos of your recent weekly summary of the progress of geography under the titles of the Death of Crevaux, etc., I may say that a member of the French geographical society, M. Thouars, accompanied the U.S. solar eclipse expedition from Panama to Callao, March 12-21, of this year. M. Thouars had familiarized himself with explorations in South America by extensive travels in Columbia and elsewhere, and intended to penetrate the Pilcomayo region, in search of the relics of the Crevaux expedition, alone, or with only one companion, the two disguised as Catholic priests. The attempt seems foolhardy; and, for my part, I am glad to know that M. Thouars intends to carry a revolver under his priest's robe, and that he is a brave man and an excellent shot.

If he has not abandoned his daring project, we should hear of him during the early part of 1884 .

Madison, Aug. 6, 1883 EDWARD S. HOLDEN.

\section{Occurrence of the swallow-tailed hawk in New Jersey.}

Early in the evening of July 28 I was standing on the brow of the bluff overlooking the Delaware River, near Bordentown, N.J., when my attention was called to a large bird sailing in comparatively small circles high overhead. Fortunately there was a dark blue-black cloud behind it, so that I had an excellent opportunity to observe the bird. It was the swallow-tailed hawk (Nauclerus forficatus). It remained in nearly the same position for over an hour, when it altered irs flight, and, with steady wingstrokes, flew rapidly in a north-west direction.

The appearance of this hawk here is one of the rarest events in the experience of New Jersey ornithologists.

Chas. C. Aввотt, M.D.

\section{A reckless flier.}

ONE might think a tragic end would await such birds as the Swifts, so bold and persistent their flight; and doubtless such is in store for many, though they seem to steer clear of most obstacles.

A case in point came recently to hand, - that of an unfortunate bird impaled to the spear-point of a lightning-rod above a chimney. There it remained until shot off with a gun, - a warning and a ghastly one, indeed, to all this swift race. F. H. Herrick.

Swallows in Boston.

I saw on the 4 th of this month the first swallow in Boston, at the extreme end of City Point, South Boston. I have been on the lookout for them since April. Two friends, good observers, report that they have not seen one this season.

Boston, Aug. 7, 1883.

Carl Rednots.

'HAs any one seen a swallow this summer in Boston?' inquires a correspondent in SCIENCE, Aug. 3. Yes: I saw six last week, perched on the state--house. Prior to this I had also raised the query. Whether it was the pugnacious sparrows, or legislature, that had banished these aerial visitors from the capitol, their old haunt, was and is a query.

Boston, Aug. 11

LEANDER WETHERELI.

\section{WARD'S DYNAMIC SOCIOLOGY.}

IV.

IT is Mr. Ward's theory, that the more complex sciences should be based upon the less complex. This he avowedly derives from 